\title{
Additive manufacturing of NiTi-Ti6Al4V multi-material cellular structures targeting orthopedic implants
}

\author{
F. Bartolomeu ${ }^{\mathrm{a}, *}$, M.M. Costa $^{\mathrm{a}}$, N. Alves $^{\mathrm{b}}$, G. Miranda ${ }^{\mathrm{a}}$, F.S. Silva ${ }^{\mathrm{a}}$ \\ ${ }^{a}$ Center for MicroElectroMechanical Systems (CMEMS-UMinho), University of Minho, Campus de Azurém, Guimarães, 4800-058, Portugal \\ ${ }^{\mathrm{b}}$ Centre for Rapid and Sustainable Product Development Polytechnic Institute of Leiria, Rua General Norton de Matos, Apartado 4133, Leiria, 2411-901, Portugal
}

\section{A R T I C L E I N F O}

\section{Keywords:}

NiTi-Ti6Al4V

Multi-material

Selective Laser Melting

Shape-memory effect

Cellular structures

Implants

\begin{abstract}
A B S T R A C T
The amount of hip revision surgeries is significantly increasing due to the loss of fixation between implant and bone, that leads to implant failure. The stiffness mismatch between Ti6Al4V hip implants and bone tissue, the non-uniform implant-bone contact pressure, and the poor wear resistance of Ti6Al4V are pointed as three critical issues that contribute to these implant's failure. In this study, a multi-material design and fabrication concept was exploited aiming to change traditional manufacturing paradigms, by allocating different biomaterials in a single component targeting a multi-functional hip implant. Selective Laser Melting technology was explored to fabricate NiTi-Ti6Al4V multi-material cellular structures with a Ti6Al4V inner region and a NiTi outer region. This work was focused on the SLM fabrication and processing parameters validation on a commercial SLM equipment. The morphological analyses allowed to assess a successful solidification and bond between NiTi and Ti6Al4V materials in the transition region. The shear tests revealed a high bond strength of the transition region with an average strength of $33 \mathrm{MPa}$. The nano-indentation results showed that the Ti6Al4V region exhibits a higher hardness and elastic modulus when compared with the NiTi region. This work is a part of a broader objective that aims to create a NiTi-Ti6Al4V multi-material and cellular structured hip implant capable to provide customized stiffness, superior wear resistance and a controlled NiTi outer region volume change.
\end{abstract}

\section{Introduction}

The demand for implants has undergone explosive growth and according to the projections for 2030, the claim for Total Hip Arthroplasty (THA) surgery is estimated to reach 4 million procedures, only in the USA [1]. Moreover, there is a high percentage of hip implant failure that leads to the need for revision surgeries, which are very expensive and painful to patients [2,3]. Also, it is known that the lifespan of a hip implant is influenced by the age of patients who undergo primary THA, being shorter in patients that have a higher level of activity [3]. In this sense, the increasing number of younger patients and the increase in the need of revision procedures is inevitable [4-6]. Revision surgeries should be avoided once they are riskier (high risk of fixation failure once there is less of hosting bone), more expensive, demanding, and invasive than primary THA surgeries [4,7]. Among all complications, the major one for this kind of surgery is the loosening of the stem and/or acetabular cup [6,7]. This loss of fixation between the implant and bone that leads to implant failure is mostly related with three issues: (1) Stiffness mismatch existing between the Ti6Al4V hip implants and the surrounding bone, that induces stress shielding, causing bone resorption and irreversible loss of implant fixation [3,7,8]. When the stress is applied to the femur, it is mostly transmitted throughout the implant (once implant material is stiffer than bone), which means that less stress is transmitted to the bone, as would naturally happen. This induces a cascade of biological events that result in bone resorption, causing, subsequently, implant loosening [2,3,9,10]; (2) Non-uniform contact pressure between the implant and nearby cortical bone, leading to a deficient stress transmission/distribution lengthwise, creating regions with high-stress concentration and other regions with almost no contact; (3) Poor wear resistance of Ti6Al4V hip implants materials [11-13]. Since the implant materials are subjected to relative micro-motions at the stem/bone interface in a corrosive environment, it is critical to reduce metal ion and wear particles released to the surrounding tissue once it can provoke toxicity and inflammatory reactions, also leading to implant failure [2,11,13-18].

Ti6Al4V alloy has been the main choice for hip implants due to its excellent mechanical and biological performance and also corrosion resistance [19]. However, these implants are still prone to failure and bone resorption commonly occurs around these implants, 10 to 15 years after THA, due to the high stiffness mismatch when comparing

\footnotetext{
* Corresponding author.

E-mail address: flaviojorgebartolomeu@gmail.com (F. Bartolomeu).
} 
the elastic modulus of Ti6Al4V $(\approx 110 \mathrm{GPa})$ with that of bone tissue (10-30 GPa) [13,20-23]. NiTi alloy has been widely used in the medical industry due to its unique properties, as shape memory effect, superelasticity, high strength, fatigue, wear, and corrosion resistance, and biocompatibility [24-26]. NiTi exhibits a higher wear resistance when compared to Ti6Al4V which can reduce the release of wear debris from the implant to the nearby biological tissues [27,28]. Also, NiTi can be designed and engineered to use the shape memory effect as an element of an active implant.

Additive Manufacturing (AM) techniques are being explored worldwide at a rapid pace, attracting many interests at industrial and academic fields due to its unparalleled potential for improving the manufacturing system, such as high flexibility, reducing material waste, the feasibility of intricate geometries, and personalized products [29]. Selective Laser Melting (SLM) is one of these techniques, that applies laser energy to selectively melt metallic powdered beds, to fabricate 3D components based on CAD data [11]. Being a layer-wise technique, by using SLM, engineers can design complex and customized solutions for a wide range of industries, which are almost impossible or unprofitable to consider when using conventional processing routes such as casting and forging $[30,31]$. SLM has been mostly used for producing metallic monomaterials for several applications including medical, aerospace, automotive, and injection molds [32-37]. However, in several applications such as orthopedic implants, components should incorporate distinct materials in different beneficial positions for achieving high-efficient and long-term solutions $[38,39]$. Several studies have been reported involving the SLM production of Ti6Al4V dense or cellular structures parts and some on Ti6Al4V-based multi-material structures [11,40-44]. Some studies can be found in literature where AM is used to fabricate multimaterial Ti6Al4V-based components such as Ti6Al4V-Invar, Ti6Al4VStainless Steel, Ti6Al4V-Inconel 718, Ti6Al4V-Al12Si [36,45-47]. To the author's best knowledge, there is no study in the literature concerning the design and SLM-production of multi-material structures gathering NiTi and Ti6Al4V materials.

Currently, biomedical cellular structured materials are in great demand once these materials can provide, simultaneously, adequate mechanical properties (strength and stiffness), physical and morphological properties, as well as a suitable ecosystem for cell seeding and bone ingrowth $[41,42,44,48,49]$. SLM technique has been used to produce mono-material Ti6Al4V and NiTi cellular structures for lowering the implant-bone stiffness mismatch [41,50-53]. In fact, just a few groups have produced quality NiTi components by SLM, due to the challenges that this alloy presents for quality production, that are strongly dependent on NiTi powder quality and suitable SLM processing parameters $[54,55]$. M. Taheri et al. [50] designed and produced by SLM NiTi porous structures with an elastic modulus varying from $16.5 \mathrm{GPa}$ (porosity of $69 \%$ ) to $41.2 \mathrm{GPa}$ (porosity of $32 \%$ ). SLM can be used to fabricate customized hip implants by using tomography 3D data from each patient, to design structured implants suited to the host bone by controlling the architecture of the porous structures [8,10,56-58]. In fact,
F. Bartolomeu et al. [41] proposed a design tool for the manufacturing of customized Ti6Al4V cubic-like cellular structures with a desired elastic modulus by adjusting the porosity and the dimensions of the structures.

In this study, multi-material NiTi-Ti6Al4V cellular structures were designed and produced by SLM to bring to life a multi-functional concept, by allocating specific local functions/materials in specific local requirements, all in a single component and produced at once. This concept aims to combine SLM design freedom, NiTi, and Ti6Al4V materials intrinsic properties and optimized cellular structures. This work is focused on the SLM fabrication validation and it is the first step of a broader objective, that aims the fabrication optimization of a NiTi-Ti6Al4V hip implant, that will be capable to address the abovementioned three implant failure issues and, consequently, reduce the need revision surgeries. This multi-material proposal can be developed for combining a Ti6Al4V inner region with an adequate mechanical strength (not assured by using a mono-material NiTi solution [59]) and stiffness, and a NiTi outer region with a controlled volume expansion (shape memory activation) to promote a suitable bone-implant contact and to induce bone ingrowth.

\section{Materials and methods}

\subsection{Materials and SLM fabrication details}

In this work, NiTi and Ti6Al4V powders were used to fabricate multimaterial NiTi-Ti6Al4V structures. $\mathrm{A} \mathrm{Ni}_{50.8} \mathrm{Ti}_{49.2}$ ingot (at.\%) purchased from SAES Smart Materials (USA) was atomized to powder by TLS Technique GmbH (Germany). The NiTi powder has a D10 of $34.64 \mu \mathrm{m}$, a D50 of $47.5 \mu \mathrm{m}$, and a D90 of $62.94 \mu \mathrm{m}$. The Ti6Al4V (ELI - grade 23) powder with a D10, D50, and D90 of $30.19,46.94$, and $71.38 \mu \mathrm{m}$, respectively, was purchased from SLM solutions (Germany). The spherical morphology of the powders is visible in Fig. $1 \mathrm{a}$ and Fig. 1b, respectively.

Selective Laser Melting technology was used to fabricate these multimaterial structures using a commercial equipment (125HL) from SLM Solutions equipped with a $400 \mathrm{~W}$ Yb-fiber laser with $87 \mu \mathrm{m}$ diameter spot. When regarding the manufacturing of Ti6Al4V, these group of authors carried out an optimization study using the same equipment [40]. A preliminary study was also performed for assessing the suitable processing parameters for NiTi and based on this background, the processing parameters (laser power, scan speed, scan spacing, and layer thickness) were defined for both materials. Table 1 shows the processing parameters used for the fabrication of the NiTi-Ti6Al4V multi-material structures, using an argon atmosphere during fabrication and a base plate preheated and maintained at $200^{\circ} \mathrm{C}$.

This works aims to be a proof of concept of the SLM potential and capability to fabricate multi-material components, by validating the manufacturing and the processing parameters. For that purpose, the fabrication of the NiTi-Ti6Al4V multi-material structures can be divided into three main steps: (1) NiTi region fabrication: in the first layer, NiTi powder was spread over the building platform being then, selectively
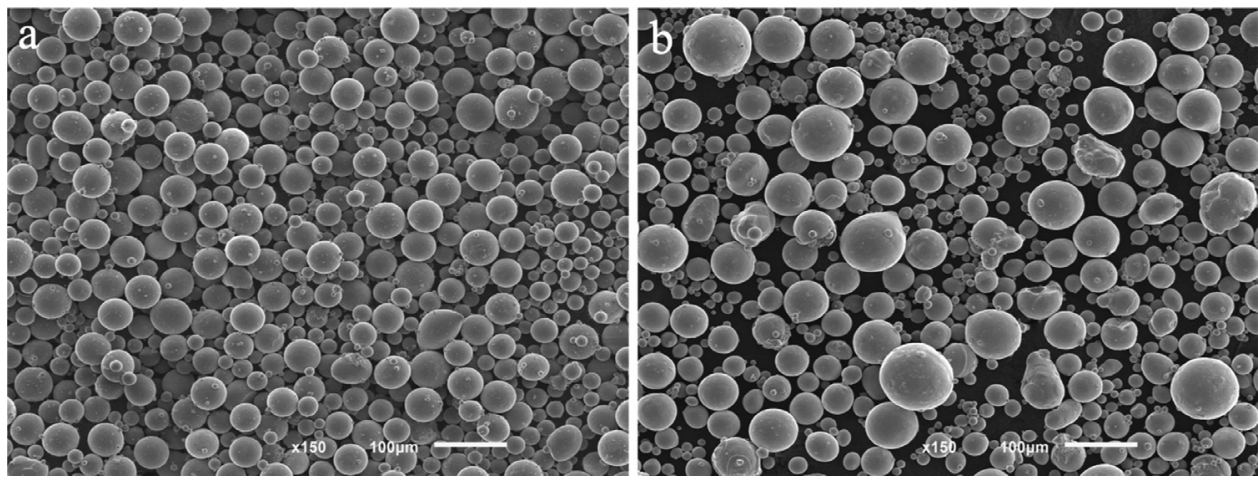

Fig. 1. SEM images of (a) Ti6Al4V and (b) NiTi powders. 
Table 1

SLM processing parameters used to fabricate the multi-material NiTi-Ti6Al4V cellular structures using a SLM 125HL equipment.

\begin{tabular}{lllll}
\hline Laser power & Scan speed & Scan spacing & Layer thickness & Energy density \\
\hline $90 \mathrm{~W}$ & $600 \mathrm{~mm} / \mathrm{s}$ & $90 \mu \mathrm{m}$ & $30 \mu \mathrm{m}$ & $55.6\left(\mathrm{~J} / \mathrm{mm}^{3}\right)$ \\
\hline
\end{tabular}

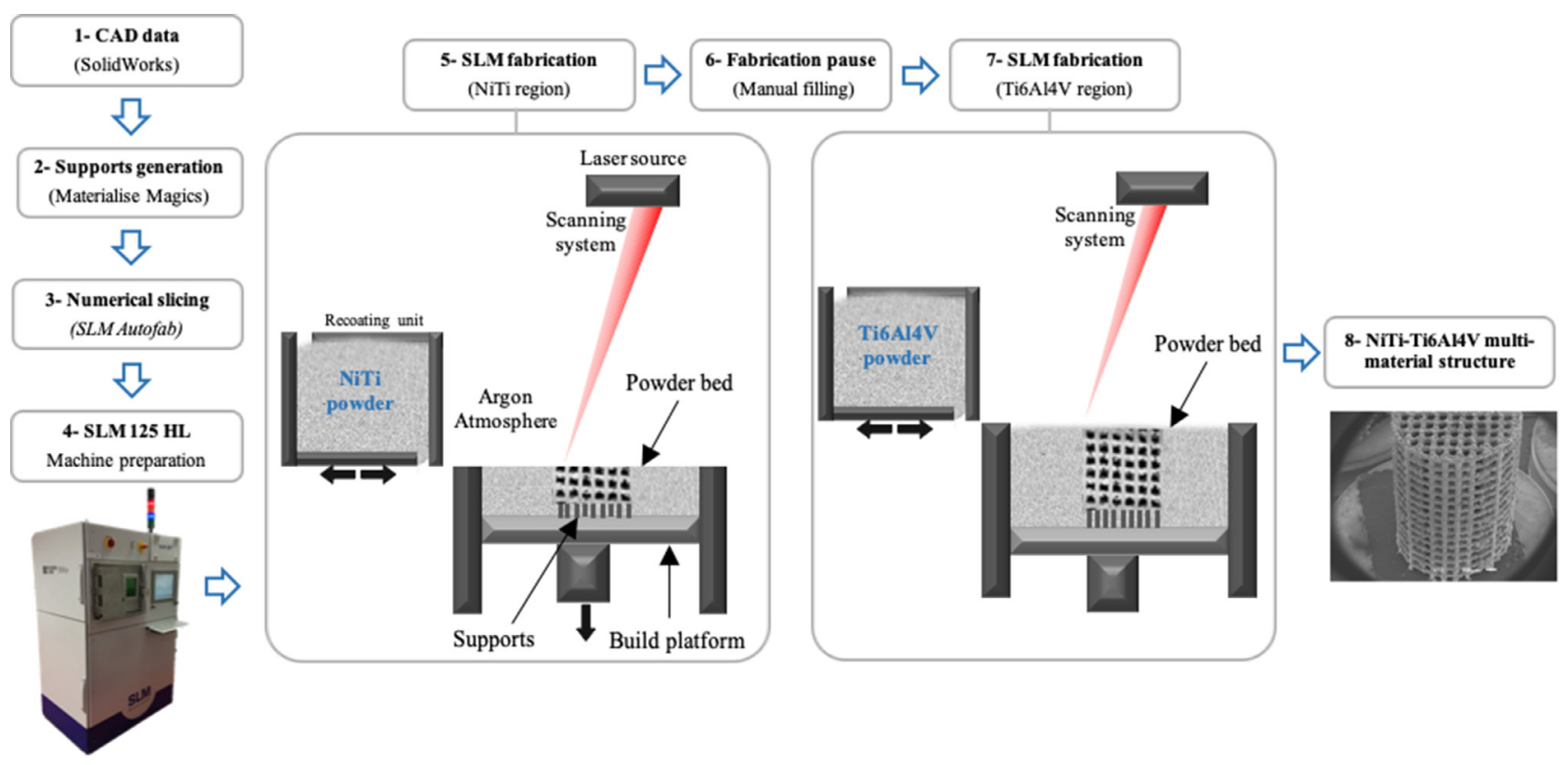

Fig. 2. Schematic representation of the NiTi-Ti6Al4V multi-material structures Selective Laser Melting fabrication.

melted by laser energy. Subsequently, in a layer-by-layer process, a new layer was deposited over the previously solidified layer, melted and consequently promoting the fusion of this layer to the previous one. This routine was repeated up to layer number 142, arbitrarily defined as the last layer of the NiTi region, corresponding to a height of $4.26 \mathrm{~mm}$; (2) Fabrication pause for manual filling: NiTi excess powder was manually removed followed by platform manual filling with Ti6Al4V power. Several passages of the recoating unit were made to assure sufficient compaction and uniform distribution, and to guarantee that the powder bed was leveled by the height of the last fabricated NiTi; (3) Ti6Al4V region fabrication: Ti6Al4V powder was spread over in layer number 143 and then, the SLM routine was repeated till the last layer (arbitrarily defined as layer number 303) corresponding to a height of $9.09 \mathrm{~mm}$. Fig. 2 aims to describe schematically, all the stages related to the production of the multi-material structures via SLM, from the CAD data to the final component.

\subsection{Multi-material implant design}

The commercially available solutions proposed by global leaders in orthopedic trauma devices such as DePuy Synthes and Zimmer Biomet are, generally, solid implants made of Ti6Al4V. When regarding hip implants, these solid solutions higher stiffness when compared to bone tissue alters drastically the mechanical stimulus naturally existing in a healthy bone. It is important to highlight that bone tissue is a selfoptimizing structure able to adapt to external loading conditions and according to Frost's mechanostat theory, the biological response of bone depends on the level of strain that is induced $[60,61]$. In this sense, the metal-bone stiffness mismatch interferes with the mechano-biological activity that should assure bone remodeling in a healthy hip, and thus, sooner or later, severe bone resorption occurs resulting in hip implant failure $[13,20,21,48]$. For that reason, this group of authors proposes a novel design for hip implants using a multi-material approach gath- ering NiTi and Ti6Al4V advantageous properties and at the same time, having a cellular structured architecture capable to promote adequate loading conditions to maintain the biological bone remodeling of the surrounding bone tissue and allowing fluid flow and bone ingrowth.

Fig. 3 aims to illustrate this study concept, showing the NiTi-Ti6Al4V cellular structures objectives based on the local requirements and functions. An outer region made of NiTi cellular structure is proposed, aiming to use the shape memory ability of this alloy to achieve an adequate implant-bone contact pressure. The inner region can be entirely Ti6Al4V cellular structures (design 1) or a combination of cellular and dense Ti6Al4V (design 2). Both multi-material designs have a transition from NiTi to Ti6Al4V cellular structures, and the second design also has a transition from cellular structured Ti6Al4V to dense Ti6Al4V. It is important to highlight that, according to literature, the mechanical strength of the martensite phase of the NiTi alloy (phase with shape memory alloy ability) exhibits a maximum yield strength of $\approx 140 \mathrm{MPa}$ while for the austenite phase this value is $\approx 690 \mathrm{MPa}$ [59]). In this sense, to use the shape memory ability of NiTi as an integrant part of a hip implant it is necessary to combine this alloy with a material capable to address the necessary mechanical requirement, such as Ti6Al4V alloy.

\subsection{Scanning electron microscopy (SEM) and X-ray diffraction analyses}

SEM (FEI Nova 200) analyses were performed to characterize the morphology of the multi-material specimens and also the NiTi-Ti6Al4V transition. Both Secondary Electron Imaging (SEI) and Backscattered Electron Imaging (BEI) were used. Additional SEM settings can be mentioned: accelerating voltage of $10 \mathrm{kV}$, high-vacuum mode, working distance between 30 and $40 \mathrm{~mm}$, and spot size of $40 \mathrm{~nm}$.

$\mathrm{X}$-ray diffraction analyses were also carried out on NiTi and Ti6Al4V regions of the multi-material specimens. A Bruker AXS D8 Discover (USA) equipment was used for performing the X-ray diffraction (XRD) 

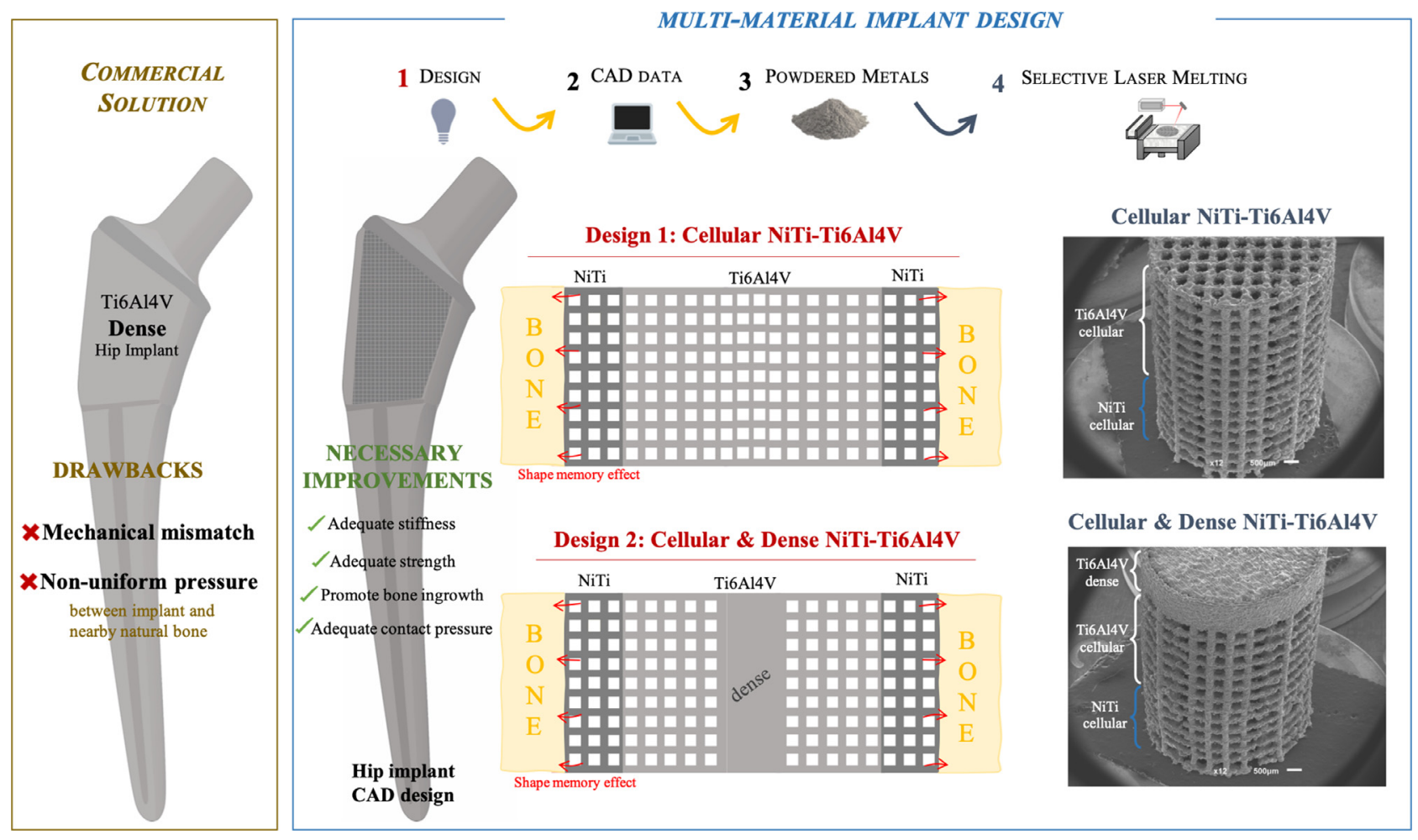

Fig. 3. Design concept of a NiTi-Ti6Al4V multi-material hip implant solution.

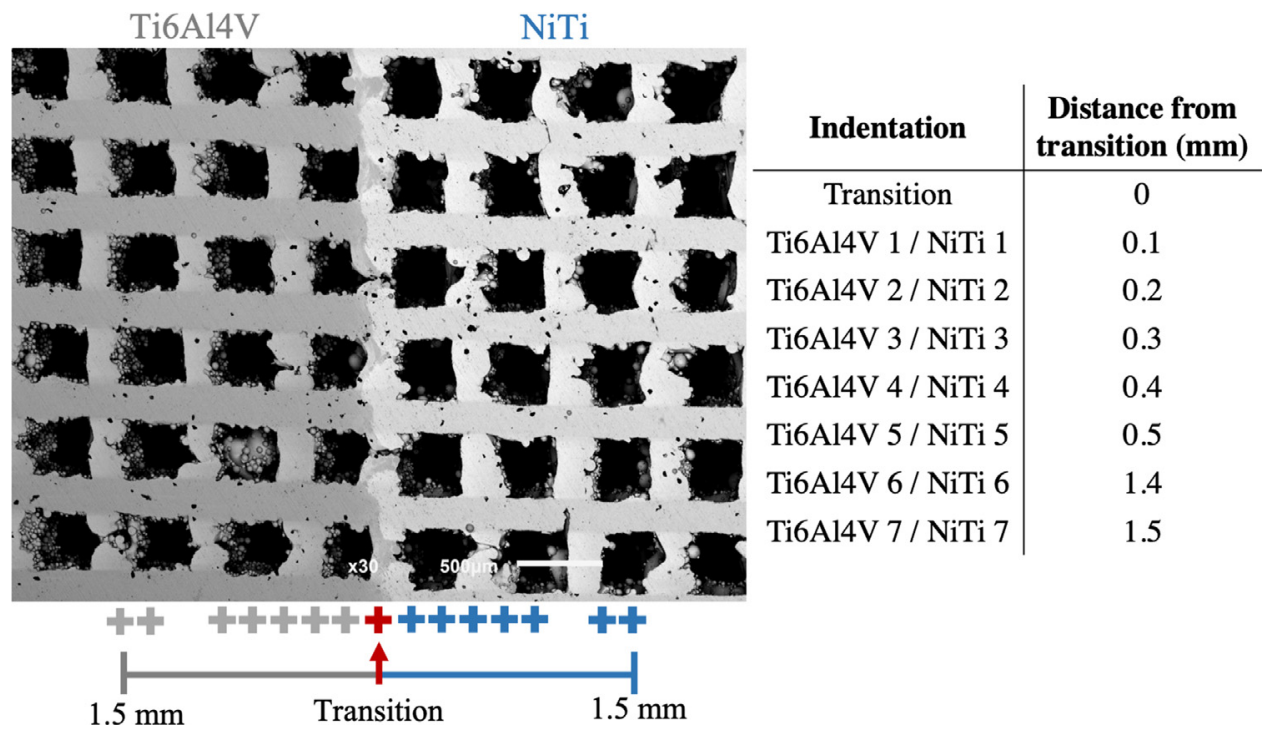

Fig. 4. Schematic representation of the crosssection of the NiTi-Ti6Al4V multi-material indicating the indentation number and the respective distance from transition.

analyses and the diffraction data was collected from $10^{\circ}$ to $90^{\circ} 2 \theta$, with a step size of $0.05^{\circ}$ and counting time of $1 \mathrm{~s} / \mathrm{step}$.

\subsection{Nanoindentation}

Nanoindentation was carried out to estimate the hardness and the elastic modulus throughout the NiTi-Ti6Al4V multi-material specimens. The specimen's cross-section was evaluated using a nanoindenter (NanoTest - Micro Materials), using a Berkovich diamond indenter. A total of 15 indentations were made along a 3mm length (see Fig. 4) using a load of $400 \mathrm{mN}$. The elastic modulus was estimated from the loaddisplacement curves, by using the following equation [62]:

$\frac{1}{E_{r}}=\frac{1-v_{i}^{2}}{E_{i}}+\frac{1-v_{m}^{2}}{E}$ where $\mathrm{E}_{\mathrm{i}}$ and $v_{\mathrm{i}}$ correspond to the elastic modulus and Poisson ratio of the diamond indenter $\left(\mathrm{E}_{\mathrm{i}}=1141 \mathrm{GPa}\right.$ and $\left.v_{\mathrm{i}}=0.07\right)$. Fig. 4 illustrates the nanoindentation test carried out using the cross-section of the NiTiTi6Al4V multi-material structure. The left side of the image corresponds to the Ti6Al4V region, while the right side corresponds to the NiTi region with the transition pointed by the red arrow.

\subsection{Bond shear strength}

The shear test was selected to assess the shear bond strength of the transition region of the NiTi-Ti6Al4V multi-materials structures and six tests were performed for on the multi-material structures. The results are presented as the average \pm standard deviation. Mono-material NiTi and Ti6Al4V specimens were also tested for comparison purposes 


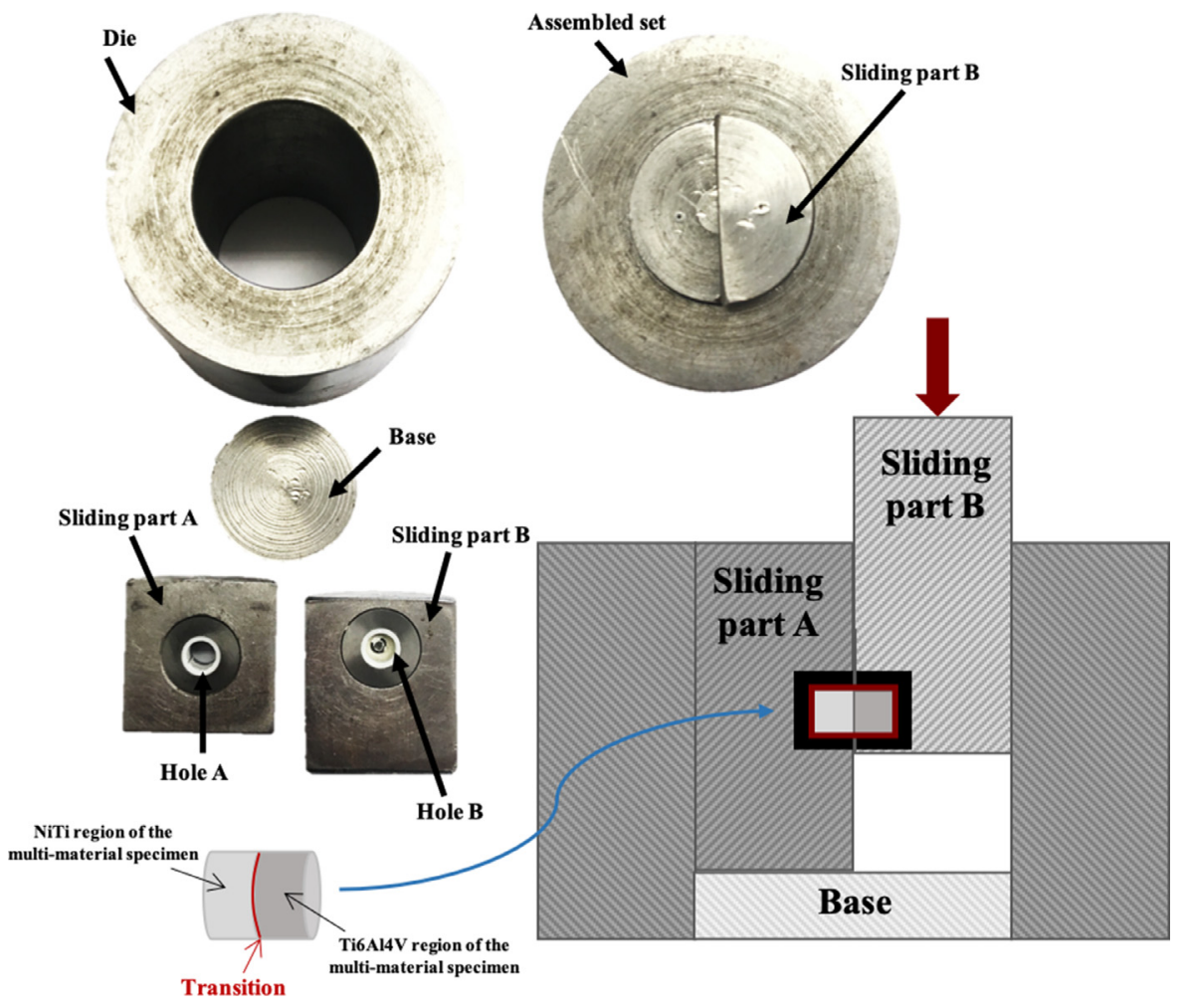

Fig. 5. Schematic representation of the custom-made device used to perform the shear bond tests in the NiTiTi6Al4V multi-material specimens. $(n=6)$. The shear tests were performed using an Instron 8874 (USA) equipped with a $25 \mathrm{kN}$ load cell under a crosshead speed of $0.05 \mathrm{~mm} / \mathrm{s}$. These tests were carried out using a custom-made device as depicted in Fig. 5.

The shear test device consists of two sliding parts (A and B), each one having two aligned holes for specimen insertion. After the insertion, the adjusting screws were used to position the specimen, aligning the transition region with the sliding part. Afterward, a downward force is applied in the upper side of part B until fracture (due to shear loading). The transition (between the dissimilar materials, NiTi and Ti6Al4V) shear bond strength (MPa) was calculated considering the maximum force $(\mathrm{N})$ and the resisting area $\left(\mathrm{mm}^{2}\right)$, obtained using a top-view SEM image of the transition.

\section{Results and Discussion}

\subsection{Morphological analyses}

In this study, two types of NiTi-Ti6Al4V multi-material structures were produced by Selective Laser Melting. The two designs have a transition between NiTi and Ti6Al4V biomaterials through a cellular structured architecture. Figs. 6 and 7 show SEM images of isometric and cross-section views of the SLM produced NiTi-Ti6Al4V multi-material structures. As seen in Fig. 3, the first design (design 1) is entirely composed of a cubic-like cellular structured architecture while the second design (design 2) has also a dense region with a respective transition from Ti6Al4V cellular structure to Ti6Al4V dense.
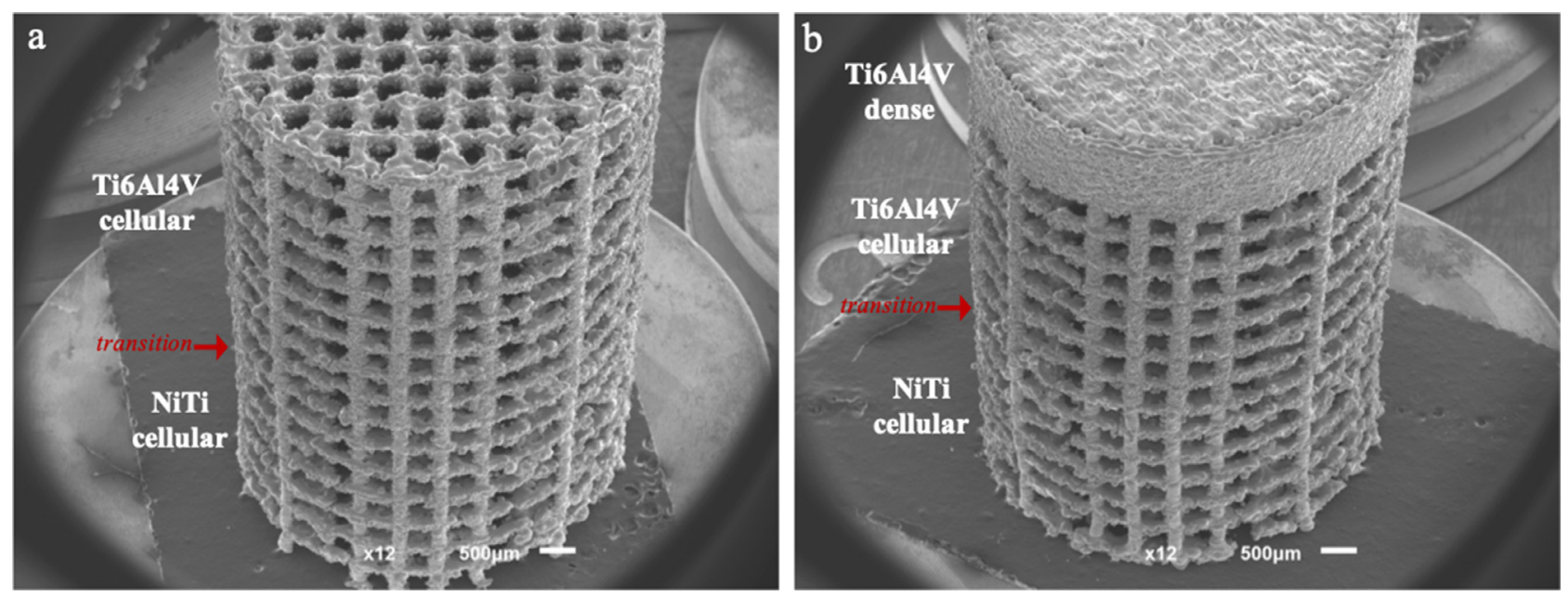

Fig. 6. SEM images of isometric views of the NiTi-Ti6Al4V multi-material structures: (a) Design 1 and (b) Design 2. 


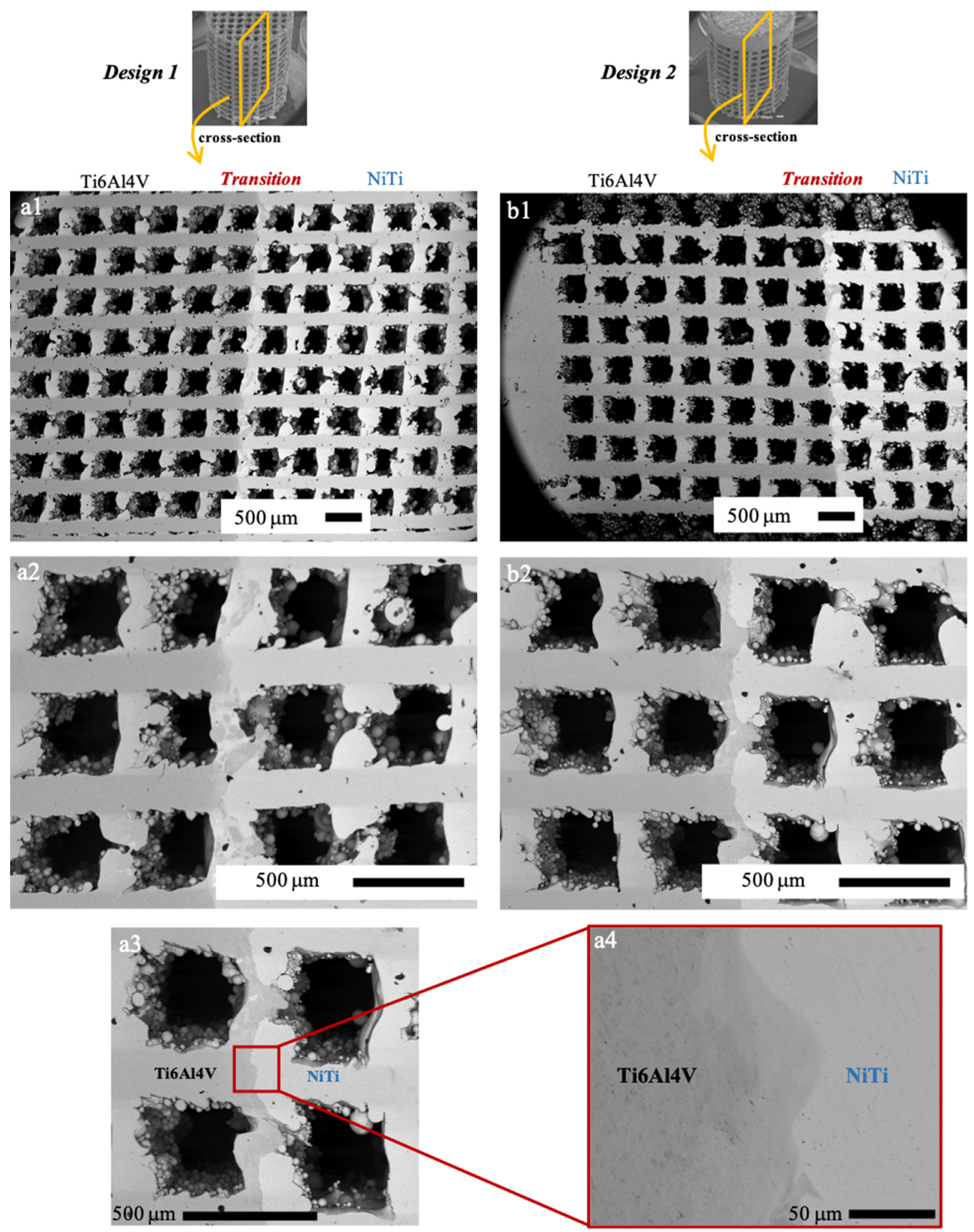

Fig. 7. SEM images of cross-section views of the NiTi-Ti6Al4V multi-material structures: (a) SP1; (b) SP2; (c) high magnification detail of the transition region of SP2 multi-material structure. 


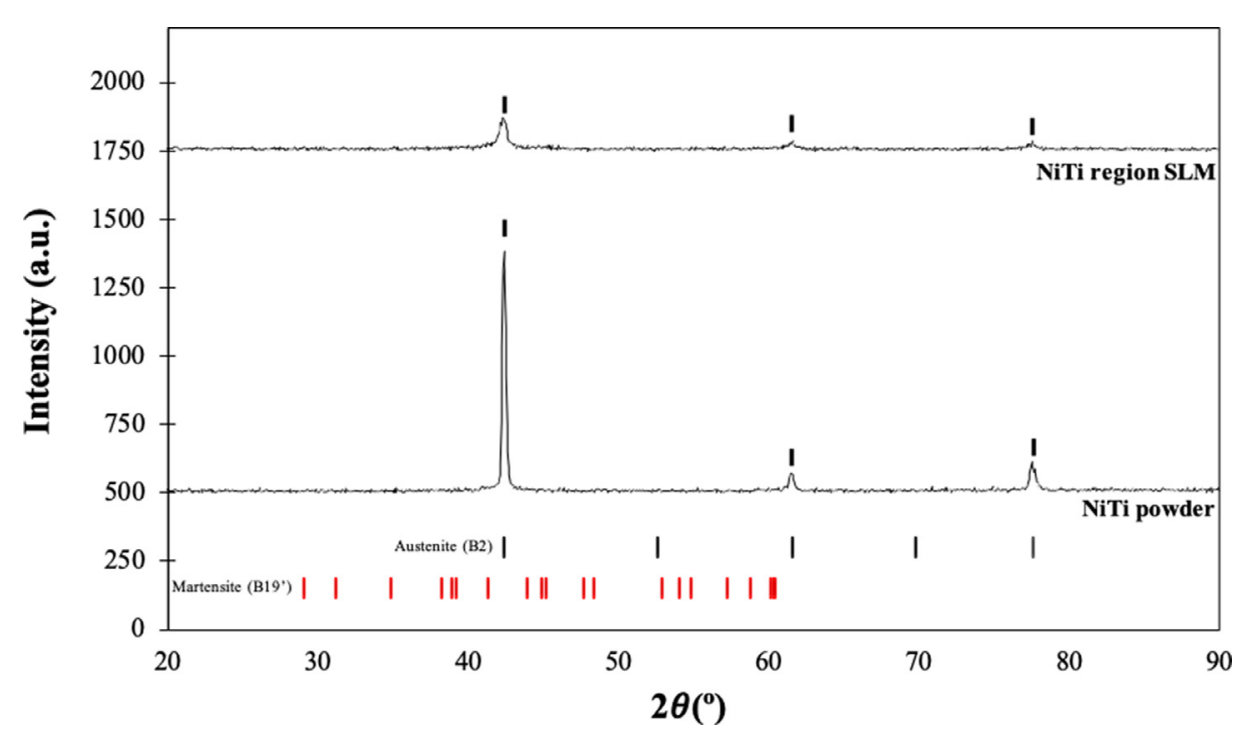

Fig. 8. X-ray diffraction patterns of NiTi powder and NiTi region of the multi-material structures produced by Selective Laser Melting (reference codes \#03-065-5746-cubic and \#00-0351281-monoclinic).
When analyzing the morphological data of the SLM produced NiTiTi6Al4V multi-material structures several aspects can be highlighted. Firstly, the SEM images allowed to assess that, successful transitions from NiTi cellular structure to Ti6Al4V cellular structure, both for design 1 and design 2, were obtained. This aspect allows to validate the adopted SLM fabrication strategy as well as to understand the adequacy of the processing parameters ( $90 \mathrm{~W}$ of laser power, $600 \mathrm{~mm} / \mathrm{s}$ of scan speed, $90 \mu \mathrm{m}$ of scan spacing, and layer thickness of $30 \mu \mathrm{m}$ ). The employed manufacturing approach allowed to obtain high-quality NiTi and Ti6Al4V cellular structures and, at the same time, achieve a good bond between these dissimilar materials. The multi-materials specimens (both in the NiTi and Ti6Al4V regions) have an interconnected cubic-like architecture with open-cell sizes of $\approx 400 \mu \mathrm{m}$ and wall sizes of $\approx 200 \mu \mathrm{m}$ (distance between two consecutive open-cells). These dimensions were defined taking into account a previous study of this group of authors [41], in which a wide range of Ti6Al4V cellular structures was mechanically tested to define suitable architectures for obtaining desired elastic modulus targeting orthopedic implants. F. Bartolomeu et al. [41] obtained an elastic modulus of $\approx 15 \mathrm{GPa}$ for the Ti6Al4V structures with open-cell and wall sizes of $\approx 400 \mu \mathrm{m}$ and $\approx 200 \mu \mathrm{m}$, which is in the range of bone tissue modulus (between 10 and $30 \mathrm{GPa}$ ) [13,20-23].
Despite using a manual strategy to remove NiTi powder and then to fill the building platform with Ti6Al4V powder (see Fig. 2), several productions were successfully concluded allowing to obtain dozens of these multi-material structures. This aspect allows to understand that this approach can be considered for regularly printing with residual samples failure. As mentioned, this study objective was the validation of a concept in which SLM design freedom, NiTi and Ti6Al4V materials intrinsic properties and optimized architecture can be combined to engineer advanced solutions to further apply in hip implants. However, it should be clarified that the manual filling approach of the present strategy, induces limitations once the variations of material can only be applied in the vertical direction and for simple shapes.

\subsection{Crystallographic analyses}

$\mathrm{X}$-ray diffraction was carried out on the starting materials (NiTi and Ti6Al4V powders) and also on the SLM-produced multi-material NiTiTi6Al4V structures as seen in Figs. 8 and 9.

Fig. 8 shows that both for NiTi powder and for the NiTi region of the multi-material structure, the XRD peaks revealed the presence of the austenite phase (B2). The diffraction patterns match with the three main peaks of the austenite phase for 2 theta of $42.436,61.571$, and $77.637^{\circ}$

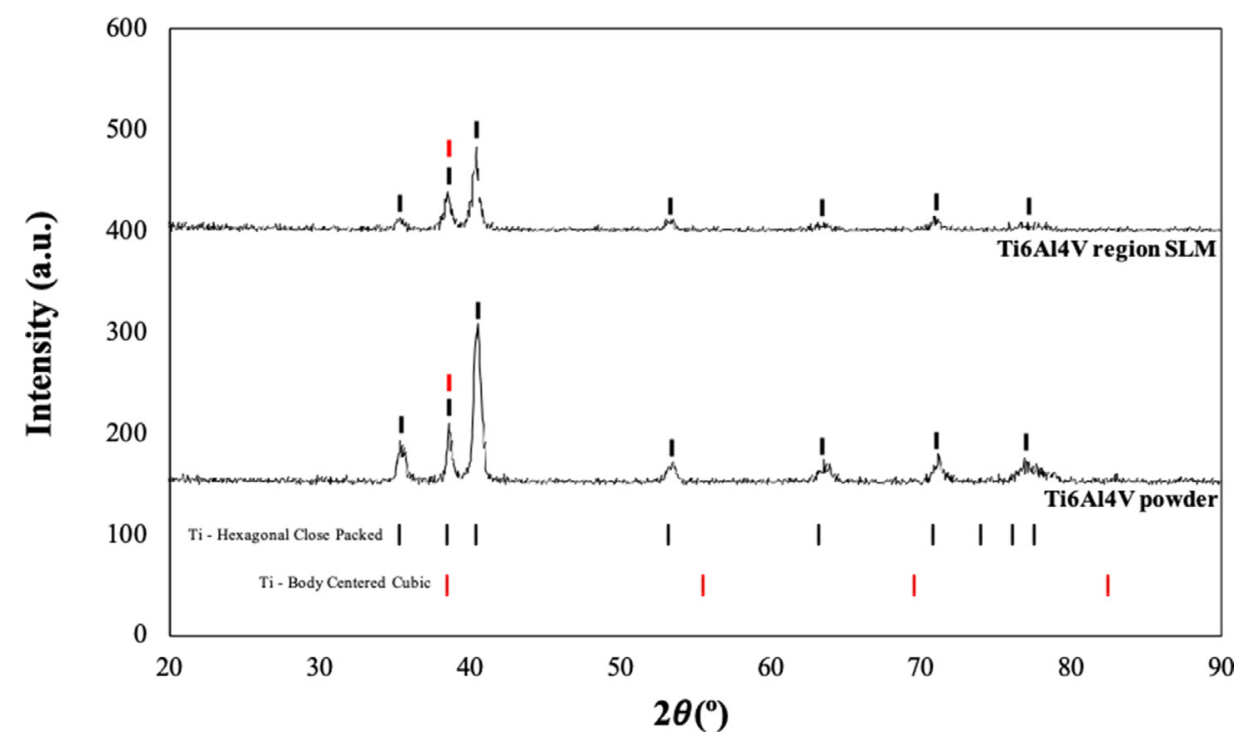

Fig. 9. X-ray diffraction pattern of Ti6Al4V powder and Ti6Al4V region of the multi-material structures produced by Selective Laser Melting (reference codes \#00-044-1288-cubic and \#00-0011198-hexagonal). 


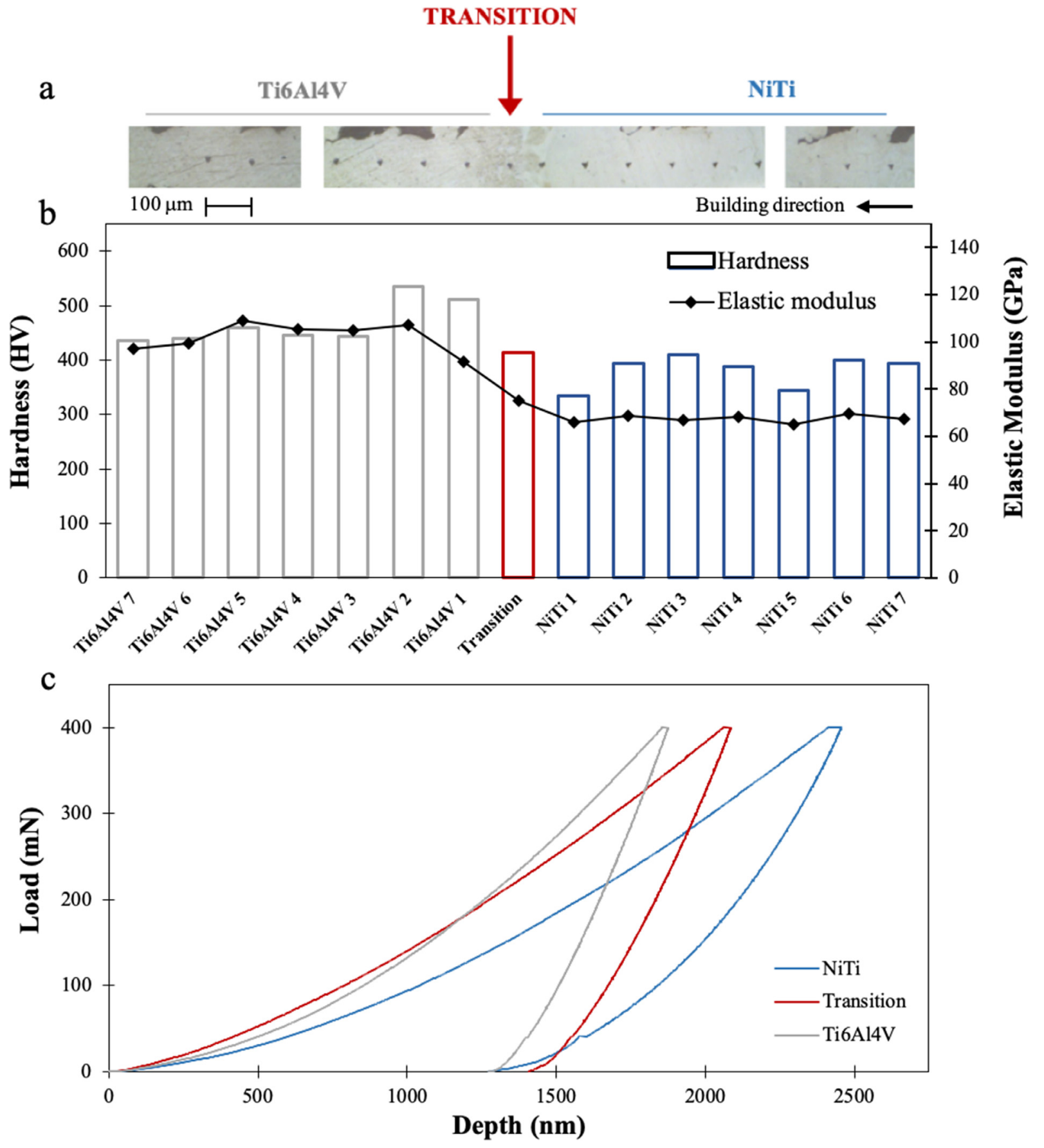

Fig. 10. Nanoindentation results: (a) Hardness and elastic modulus and (b) load-displacement curves.

(reference code: 03-065-5746). Also, there is no evidence of the presence of the martensite phase (B19') and also of any other intermetallic phases (such as $\mathrm{Ti}_{2} \mathrm{Ni}$ ).

X-ray patterns depicted in Fig. 9 show that for Ti6Al4V powder and Ti6Al4V region of the multi-material structure, similar peaks are found, revealing the presence of Ti Hexagonal Close Packed (HCP) that can correspond to $\alpha$ or $\alpha$ ' phases, which have the same crystalline structure. The main peak of Ti Body-Centered Cubic (BCC) is at $38.482^{\circ}$ and $\mathrm{Ti}$ HCP has a peak near $38.439^{\circ}$. For that reason, this peak was identified as HCP or BCC in Fig. 9.

\subsection{Mechanical analyses}

Fig. 10 shows the summary of the results obtained from the nanoindentation tests, in which Fig. 10 (a) depicts the indentations performed on the multi-material structure, Fig. 10 (b) shows the hardness and the elastic modulus results, and Fig. 10 (c) shows three typical load-displacement curves selected for NiTi, Ti6Al4V and transition regions. A total of fifteen indentations were made on the NiTi-Ti6Al4V multi-material cellular structure, seven in the NiTi region, seven in the Ti6Al4V region, and one in the materials transition. 


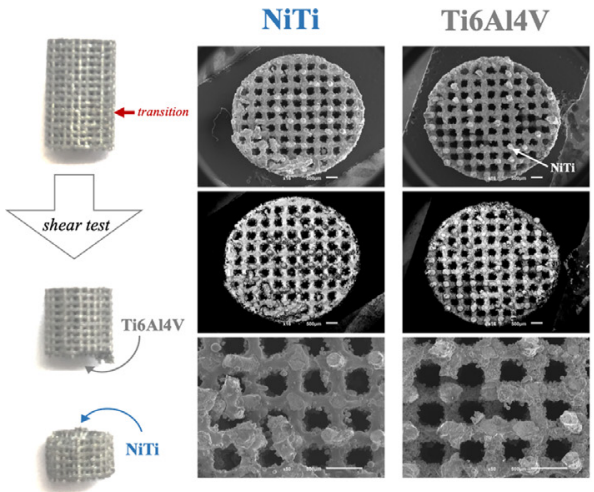

Design 1 - NiTi-Ti6Al4V structured

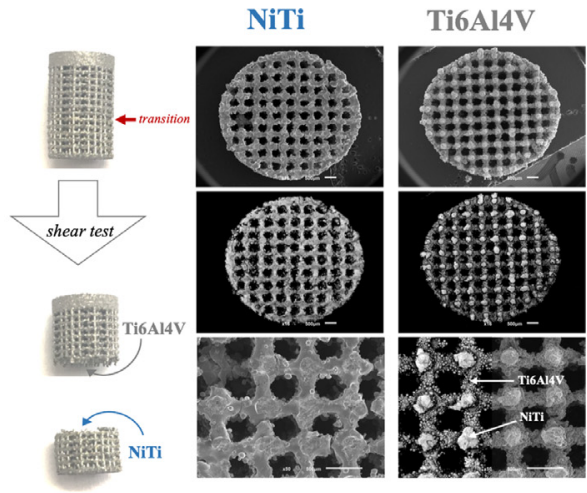

Design 2 - NiTi-Ti6Al4V structured \& dense
Fig. 11. SEM images of NiTi-Ti6Al4V multimaterial structures (design 1 and design 2) obtained after performing shear bond tests.
The nano-indentation results show, in general, lower values of hardness and elastic modulus in the NiTi region (NiTi 1 to NiTi 7) in comparison to the Ti6Al4V region (Ti6Al4V 1 to Ti6Al4V 7). The hardness values obtained in NiTi region varied from 335 to $410 \mathrm{HV}$, while in the Ti6Al4V region varied from 440 to $534 \mathrm{HV}$. On the other hand, the elastic modulus ranged from 68 to $73 \mathrm{GPa}$ in the NiTi region and from 91 to $109 \mathrm{GPa}$ in the Ti6Al4V region. In-between values were obtained in the transition region both for the hardness $(415 \mathrm{HV})$ and the elastic modulus (79 GPa). The load-displacement curves (Fig. 10 (b)) show a higher penetration depth for the NiTi region $(2457 \mathrm{~nm})$ when compared to the Ti6Al4V region $(1876 \mathrm{~nm})$, while the indentation performed on the transition exhibits an intermediate penetration depth of $2086 \mathrm{~nm}$. The hardness depends on the penetration depth of the plastic deformation, while the elastic modulus is related to the elastic stress fields and the slope of the unloading curve [63]. The average hardness of $\approx 4.94$ $\pm 0.38 \mathrm{GPa}(468 \pm 36 \mathrm{HV})$ obtained in the Ti6Al4V region is in accordance with several studies carried out on Ti6Al4V parts fabricated by Selective Laser Melting [64-67]. W. Kao et al. [68] produced Ti6Al4V parts via SLM and the average hardness was $3.82 \pm 0.029 \mathrm{GPa}(390 \pm 3$ $\mathrm{HV})$. When regarding the hardness results in the NiTi region, an average value of $4.03 \pm 0.29 \mathrm{GPa}(381 \pm 27 \mathrm{HV})$ was observed which is coherent with literature. J. Marattukalam et al. [69] produced NiTi specimens by Laser Engineered Net Shaping (LENS) using equiatomic NiTi pre-alloyed spherical powders and the hardness results ranged from 238 to $334 \mathrm{HV}$, depending on the laser energy density (from 20 to $80 \mathrm{~J} / \mathrm{mm}^{3}$ ). Also, S. Kumar et al. [70] performed hardness tests on NiTi parts produced by
LENS and the obtained results were $\approx 300 \mathrm{HV}$, thus comparable to those obtained in the present study. Despite using the same energy density $(\approx$ $55 \mathrm{~J} / \mathrm{mm}^{3}$ ), S. Saedi et al. [71] reported an average value of $230 \pm 25$ $\mathrm{HV}$, which is $40 \%$ lower when compared to the present study.

Shear tests were carried out to assess the NiTi-Ti6Al4V shear bond strength and the average results \pm standard deviation are present in Table 2. It is important to highlight that the positioning of the specimens in the home-made device accommodates the all system in a manner that the sliding occurred between the sliding parts A and B, causing the fracture to occur in the transition region (see Fig. 5).

As can be seen in Table 2, mono-material NiTi and Ti6Al4V cellular structures (having the same architecture and being produced using the same processing parameters) were also tested for comparison purposes. The shear bond strength obtained for the multi-material structures was $\approx 33.2 \mathrm{MPa}$ which shows that a significant mechanical interlocking was obtained in the transition between the dissimilar materials. When comparing the multi-material structures results with the monomaterial structures, it can be observed a $23 \%$ lower strength in the case of the NiTi mono-material structures $(\approx 25.5 \pm 4.8 \mathrm{MPa})$ and a $43 \%$ higher strength for the Ti6Al4V mono-material structures $(\approx 47.4 \pm 4.0$ $\mathrm{MPa}$ ). The higher shear strength of Ti6Al4V mono-material when compared both with multi-material NiTi-Ti6Al4V and mono-material NiTi structures can be explained based on the higher mechanical resistance of Ti6Al4V compared to NiTi [59,72]. Studies in the literature regarding NiTi or Ti6Al4V shear strength are very scarce. Zuhao Li et al. [73] investigated the shear properties of Electron Beam Melting Ti6A14V do-
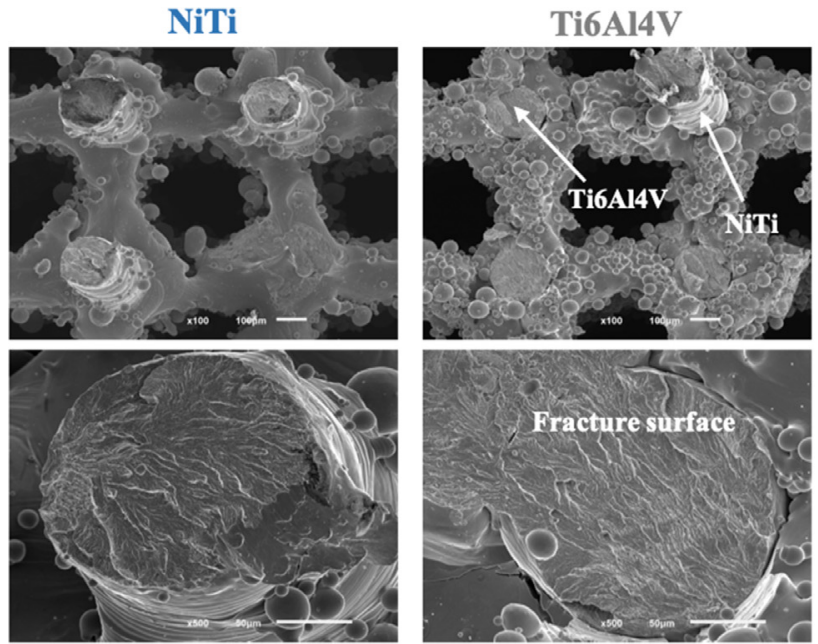

Design 1 - NiTi-Ti6Al4V structured
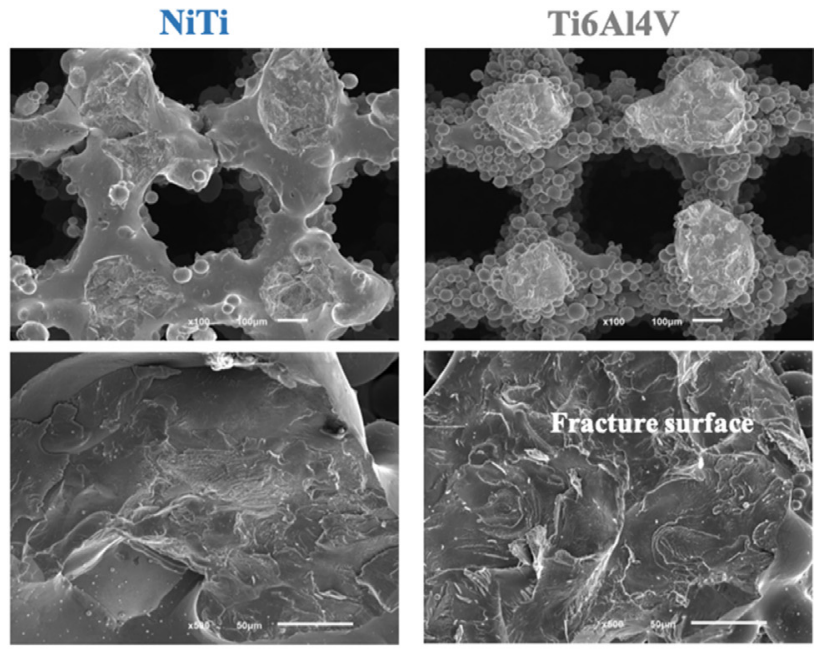

Design 2 - NiTi-Ti6Al4V structured \& dense

Fig. 12. SEM images showing details of the fracture surfaces of the NiTi-Ti6Al4V multi-material structures (Design 1 and Design 2) 
Table 2

Shear strength results (average \pm standard deviation) of the NiTi-Ti6Al4V multi-material structures and the NiTi and Ti6Al4V mono-material structures.

\begin{tabular}{llll}
\hline & Multi-material & Mono-material & \\
\hline & NiTi-Ti6Al4Vcellular structures & NiTi cellular structures & Ti6Al4V cellular structures \\
Shear strength (MPa) & $33.2 \pm 5.3$ & $25.5 \pm 4.8$ & $47.1 \pm 4.0$ \\
\hline
\end{tabular}

decahedron scaffolds with an open-cell and wall sizes of 800 and 300 $\mu \mathrm{m}$, respectively. Although this study does not indicate the shear tests positioning of the specimens and considering the different specimen's geometries and dimensions when comparing to the present study, a comparable shear strength ( $\approx 33.5 \mathrm{MPa}$ ) was reported. Figs. 11 and 12 shows SEM images of the multi-material structures (SP1 and SP2) after shear testing. As expected, due to the shear device geometry, the fractures occurred near to the materials transition for all the shear tests and it is not clear a prevalent failure in NiTi or Ti6Al4V regions. Both SP1 and SP2 multi-material structures exhibit a similar fracture behavior with surface fractures exhibiting extensive plastic deformation similar to those observed elsewhere [74]. As can be seen in Fig. 12, the fracture occurred in the top or bottom of the pillars nearby the material's transition of the structures.

\subsection{Future challenges on the SLM fabrication of NiTi-Ti6Al4V multi-material implants}

The present study was focused on the validation of a multi-material fabrication strategy using a Selective Laser Melting commercial equipment. Despite the successful assessment in terms of the processing parameters, that allowed to obtain high-quality NiTi-Ti6Al4V multimaterial parts, the approach adopted in this work requires further developments to reach more complex multi-material solutions. In the author's opinion, the upgrade of the existing SLM systems is a crucial milestone for fabricating high-complexity and multi-functional solutions (that integrate different materials and architectures such as NiTi-Ti6Al4V) not achievable by conventional processing routes or by using mono-material components [11,75].

The SLM fabrication of NiTi-Ti6Al4V multi-material products requires the development of an advanced Selective Laser Melting equipment with the simultaneous use of two materials (filling and removing powder automatic systems) for obtaining the desired transitions in $\mathrm{xx}$, yy and zz directions. The NiTi shape memory effect can be used for assuring an adequate bone-implant contact pressure which requires an outer volume change capability to assure a uniform loading condition and not surpassing bone yield strength of $\approx 120 \mathrm{MPa}$ [76]. Also, several challenging aspects are being investigated regarding the SLM processing parameters and thermal treatments to tailor the transformation temperature and the suited thickness, and the necessary deformation (material training) that allows obtaining the desired recovery strain. This multimaterial proposed solution will be further developed by this group of authors aiming to combine a Ti6Al4V inner region with adequate mechanical strength and stiffness, and a NiTi outer region with a controlled volume expansion to promote a suitable bone-implant contact pressure, while allowing bone ingrowth.

\section{Conclusion}

In this study, NiTi-Ti6Al4V multi-material cellular structures were designed and produced by Selective Laser Melting using a commercial equipment (SLM 125 HL from SLM Solutions). The SLM strategy for the production of the multi-materials structures was validated. The manufacturing started with the NiTi region printing and then, a manual procedure was used to remove the NiTi excess powder and to fill the platform with Ti6Al4V power. The SLM processing parameters, $90 \mathrm{~W}$ of laser power, $600 \mathrm{~mm} / \mathrm{s}$ of scan speed, $90 \mu \mathrm{m}$ of scan spacing and layer thickness of $30 \mu \mathrm{m}$, allow obtaining high-quality NiTi-Ti6Al4V structures, while the morphological analyses and the shear test results indicated an effective bonding between the NiTi and Ti6Al4V materials in the transition region with a shear bond strength of $\approx 33 \mathrm{MPa}$. The X-ray diffractions patterns show the presence of the austenite phase on the NiTi region, which indicates that further investigations regarding thermal treatments are necessary to obtain the martensite shape-memory phase. Regarding nanoindentation tests, the results showed higher values of hardness and elastic modulus on the Ti6Al4V region when compared to the NiTi region and the interface. To sum, this study aims to outline a design and fabrication strategy for hip implants capable to gather NiTi and Ti6Al4V biomaterials in a single component. Arising studies are being carried out related with the activating and controlling of NiTi shape memory ability in the outer region of NiTi-Ti6Al4V multi-material structures.

\section{Declaration of Competing Interest}

None.

\section{CRediT authorship contribution statement}

F. Bartolomeu: Methodology, Validation, Investigation, Writing original draft, Writing - review \& editing, Visualization. M.M. Costa: Methodology, Investigation, Visualization. N. Alves: Resources, Funding acquisition. G. Miranda: Conceptualization, Investigation, Resources, Writing - review \& editing, Supervision, Project administration, Funding acquisition. F.S. Silva: Conceptualization, Resources, Writing - review \& editing, Supervision, Project administration, Funding acquisition.

\section{Acknowledgements}

This work was supported by FCT (Fundação para a Ciência e a Tecnologia) through the grant SFRH/BD/128657/2017 and the projects PTDC/EMS-TEC/5422/2014_ADAPTPROSTHESIS and UID/EEA/04436/2019.

\section{References}

[1] H.M. Kremers, D.R. Larson, C.S. Crowson, W.K. Kremers, R.E. Washington, C.A. Steiner, W.A. Jiranek, D.J. Berry, Prevalence of Total Hip and Knee Replacement in the United States, (2015) 1386-1397.

[2] Geetha M, Singh AK, Asokamani R, Gogia AK. Ti based biomaterials, the ultimate choice for orthopaedic implants. A review, Prog. Mater. Sci. 2009;54:397-425. doi:10.1016/j.pmatsci.2008.06.004.

[3] Holzwarth U, Cotogno G. Total Hip Arthroplasty - State of the Art, Challenges and Prospects,. J. Bone Jt. Surg. Inc. 2012. doi:10.2788/31286.

[4] MD SJF. 100 Questions \& Answers About Hip Replacement. Jones and 2010.

[5] Shrader MW. Total Hip Arthroplasty and Hip Resurfacing Arthroplasty in the Very Young Patient. Orthop. Clin. North Am. 2012;43:359-67. doi:10.1016/j.ocl.2012.05.005.

[6] Ulrich SD, Seyler TM, Bennett D, Delanois RE, Saleh KJ, Thongtrangan I, Kuskowski M, Cheng EY, Sharkey PF, Parvizi J, Stiehl JB, Mont MA. Total hip arthroplasties: What are the reasons for revision? Int. Orthop. 2008;32:597-604. doi:10.1007/s00264-007-0364-3.

[7] Affatato S. Perspectives in Total Hip Arthroplasty - Advances in Biomaterials and their Tribological Interactions. Woodhead P 2014. doi:10.1016/B978-1-78242-031-6.50016-7.

[8] Yan C, Hao L, Hussein A, Young P. Ti-6Al-4V triply periodic minimal surface structures for bone implants fabricated via selective laser melting. J. Mech. Behav. Biomed. Mater. 2015;51:61-73. doi:10.1016/j.jmbbm.2015.06.024. 
[9] Varini E. Primary stability in cementless total hip replacement: measurement techniques and aided-surgery, J. Biomech. 2007.

[10] Chen Q, Thouas GA. Metallic implant biomaterials, Mater. Sci. Eng. R Reports 2015;87:1-57. doi:10.1016/j.mser.2014.10.001.

[11] Bartolomeu F, Buciumeanu M, Costa MM, Alves N, Gasik M, Silva FS, Miranda G. Multi-material Ti6Al4V \& PEEK cellular structures produced by Selective Laser Melting and Hot Pressing : A tribocorrosion study targeting orthopedic applications, J. Mech. Behav. Biomed. Mater. 2019;89:54-64. doi:10.1016/j.jmbbm.2018.09.009.

[12] Moura CG, Pereira R, Buciumeanu M, Carvalho O, Bartolomeu F, Nascimento R, Silva FS. Effect of laser surface texturing on primary stability and surface properties of zirconia implants. Ceram. Int. 2017;43 15227-15236. doi:10.1016/j.ceramint.2017.08.058.

[13] Bose S, Ke D, Sahasrabudhe H, Bandyopadhyay A. Progress in Materials Science Additive manufacturing of biomaterials. Prog. Mater. Sci. 2018;93:45-111. doi:10.1016/j.pmatsci.2017.08.003.

[14] Rodrigues DC, Valderrama P, Wilson TG, Palmer K, Thomas A, Sridhar S, Adapalli A, Burbano M, Wadhwani C. Titanium corrosion mechanisms in the oral environment: A retrieval study. Materials (Basel) 2013;6:5258-74. doi:10.3390/ma6115258.

[15] Ganesh BKC, Ramanaih N, Chandrasekhar Rao PV. Dry Sliding Wear Behavior of Ti6Al-4V Implant Alloy Subjected to Various Surface Treatments. Trans. Indian Inst. Met. 2012;65:425-34. doi:10.1007/s12666-012-0147-4.

[16] Goodman SB. Wear particles, periprosthetic osteolysis and the immune system. Biomaterials 2007;28:5044-8. doi:10.1016/j.biomaterials.2007.06.035.

[17] Runa MJ, Mathew MT, Rocha LA. Tribocorrosion response of the Ti6Al4V alloys commonly used in femoral stems. Tribol. Int. 2013;68:85-93. doi:10.1016/j.triboint.2013.09.022.

[18] Toptan F, Alves AC, Carvalho Ó, Bartolomeu F, Pinto AMP, Silva F, Miranda G. Corrosion and tribocorrosion behaviour of Ti6Al4V produced by selective laser melting and hot pressing in comparison with the commercial alloy. J. Mater. Process. Tech. 2019;266:239-45. doi:10.1016/j.jmatprotec.2018.11.008.

[19] Yan X, Li O, Yin S, Chen Z, Jenkins R, Chen C, Wang J, Ma W, Bolot R, Lupoi R, Ren Z. Mechanical and in vitro study of an isotropic Ti6Al4V lattice structure fabricated using selective laser melting. J. Alloys Compd 2019;782:209-23. doi:10.1016/j.jallcom.2018.12.220.

[20] S.Y. Chen, J.C. Huang, C.T. Pan, C.H. Lin, T.L. Yang, Y.S. Huang, C.H. Ou, L.Y. Chen, D.Y. Lin, H.K. Lin, T.H. Li, J.S.C. Jang, C.C. Yang, Microstructure and mechanical properties of open-cell porous Ti-6Al- $4 \mathrm{~V}$ fabricated by selective laser melting, 713 (2017) 248-254. doi:10.1016/j.jallcom.2017.04.190.

[21] M. Fousová, D. Vojt, E. Jablonská, J. Fojt, Journal of the Mechanical Behavior of Biomedical Materials Promising characteristics of gradient porosity Ti-6Al-4V alloy prepared by SLM process, 69 (2017) 368-376. doi:10.1016/j.jmbbm.2017.01.043.

[22] Capek J, Machová M, Fousová M, Kubbásek J, Vojtechch D, Fojt J, Jablonská E, Lipov J, Ruml T. Highly porous, low elastic modulus 316L stainless steel scaffold prepared by selective laser melting. Mater. Sci. Eng. C. 2016;69:631-9. doi:10.1016/j.msec.2016.07.027.

[23] Wittenberg RH, Steffen R, Windhagen H, Bücking P, Wilcke A. Five-year results of a cementless short-hip-stem prosthesis. Orthop. Rev. (Pavia). 2013;5:e4. doi:10.4081/or.2013.e4.

[24] Zhou Q, Dilawer M, Chen G, Cai S, Qu X. Materials Science \& Engineering A Selective electron beam melting of NiTi : Microstructure, phase transformation and mechanical properties. Mater. Sci. Eng. A. 2019;744:290-8. doi:10.1016/j.msea.2018.12.023.

[25] Speirs M, Van Hooreweder B, Van Humbeeck J, Kruth J. Journal of the Mechanical Behavior of Biomedical Materials Fatigue behaviour of NiTi shape memory alloy sca ff olds produced by SLM, a unit cell design comparison, J. Mech. Behav. Biomed. Mater. 2017;70:53-9. doi:10.1016/j.jmbbm.2017.01.016.

[26] Dadbakhsh S, Speirs M, Kruth J, Van Humbeeck J. CIRP Annals - Manufacturing Technology Influence of SLM on shape memory and compression behaviour of NiTi scaffolds. CIRP Ann. - Manuf. Technol. 2015;64:209-12. doi:10.1016/j.cirp.2015.04.039.

[27] M.H. Elahinia, M. Hashemi, M. Tabesh, Progress in Materials Science Manufacturing and processing of NiTi implants : A review, 57 (2012) 911-946. doi:10.1016/j.pmatsci.2011.11.001.

[28] Waghmare DT, Padhee CK, Prasad R, Masanta M. NiTi coating on Ti-6Al-4V alloy by TIG cladding process for improvement of wear resistance : Microstructure evolution and mechanical performances. J. Mater. Process. Tech. 2018;262:551-61. doi:10.1016/j.jmatprotec.2018.07.033.

[29] Gisario A, Kazarian M, Martina F, Mehrpouya M. Metal additive manufacturing in the commercial aviation industry: A review, J. Manuf. Syst. 2019;53:124-49. doi:10.1016/j.jmsy.2019.08.005.

[30] Bartolomeu F, Buciumeanu M, Pinto E, Alves N, Silva FS, Carvalho O, Miranda G. Wear behavior of Ti6Al4V biomedical alloys processed by selective laser melting, hot pressing and conventional casting. Trans. Nonferrous Met. Soc. China 2017;27:82938 English Ed. doi:10.1016/S1003-6326(17)60060-8.

[31] Buciumeanu M, Almeida S, Bartolomeu F, Costa MM, Alves N, Silva FS, Miranda G. Ti6Al4V cellular structures impregnated with biomedical PEEK - New material design for improved tribological behavior. Tribol. Int. 2018;119:157-64. doi:10.1016/j.triboint.2017.10.038.

[32] Saedi S, Turabi AS, Andani MT, Moghaddam NS, Elahinia M, Karaca H, Texture aging. and superelasticity of selective laser melting fabricated Ni-rich NiTi alloys. Mater. Sci. Eng. A. 2017;686:1-10. doi:10.1016/j.msea.2017.01.008.

[33] Hosseini E, Popovich VA. A review of mechanical properties of additively manufactured Inconel 718. Addit. Manuf. 2019;30 100877. doi:10.1016/j.addma.2019.100877
[34] Aboulkhair NT, Simonelli M, Parry L, Ashcroft I, Tuck C, Hague R. 3D printing of Aluminium alloys: Additive Manufacturing of Aluminium alloys using selective laser melting. Prog. Mater. Sci. 2019;106 100578. doi:10.1016/j.pmatsci.2019.100578.

[35] Ma Z, Zhang DZ, Liu F, Jiang J, Zhao M, Zhang T. Lattice structures of Cu-Cr-Zr copper alloy by selective laser melting: Microstructures, mechanical properties and energy absorption. Mater. Des. 2020;187 108406. doi:10.1016/j.matdes.2019.108406.

[36] Zhang Y, Bandyopadhyay A. Direct fabrication of bimetallic Ti6Al4V + Al12S structures via additive manufacturing. Addit. Manuf. 2019;29 100783. doi:10.1016/j.addma.2019.100783.

[37] Onuike B, Bandyopadhyay A. Bond strength measurement for additively manufactured Inconel 718- GRCop84 copper alloy bimetallic joints. Addit. Manuf. 2019;27:576-85. doi:10.1016/j.addma.2019.04.003.

[38] Chen J, Yang Y, Song C, Zhang M, Wu S, Wang D. Interfacial microstructure and mechanical properties of $316 \mathrm{~L} / \mathrm{CuSn} 10$ multi-material bimetallic struc ture fabricated by selective laser melting. Mater. Sci. Eng. A. 2019;752:75-85. doi:10.1016/j.msea.2019.02.097.

[39] Demir AG, Previtali B. Multi-material selective laser melting of Fe/Al-12Si components. Manuf. Lett. 2017;11:8-11. doi:10.1016/j.mfglet.2017.01.002.

[40] Bartolomeu F, Faria S, Carvalho O, Pinto E, Alves N, Silva FS, Miranda G. Predictive models for physical and mechanical properties of Ti6Al4V produced by Selective Laser Melting. Mater. Sci. Eng. A. 2016;663:181-92. doi:10.1016/j.msea.2016.03.113

[41] Bartolomeu F, Fonseca J, Peixinho N, Alves N, Gasik M, Silva FS, Miranda G. Predicting the output dimensions, porosity and elastic modulus of additive manufactured biomaterial structures targeting orthopedic implants, J. Mech. Behav. Biomed. Mater. 2019;99:104-17. doi:10.1016/j.jmbbm.2019.07.023.

[42] Melo-Fonseca F, Lima R, Costa MM, Bartolomeu F, Alves N, Miranda A, Gasik M, Silva FS, Silva NA, Miranda G, structures 45S5 BAG-Ti6Al4V. The influence of the design on some of the physical and chemical interactions that drive cellular response. Mater. Des. 2018;160:95-105. doi:10.1016/j.matdes.2018.08.056.

[43] Bartolomeu F, Abreu CS, Moura CG, Costa MM, Alves N, Silva FS, Miranda G. Ti6Al4V-PEEK multi-material structures - design, fabrication and tribological characterization focused on orthopedic implants. Tribol. Int. 2018;131:672-8. doi:10.1016/j.triboint.2018.11.017.

[44] Costa MM, Lima R, Melo-Fonseca F, Bartolomeu F, Alves N, Miranda A, Gasik M, Silva FS, Silva NA, Miranda G. Development of $\beta$-TCP-Ti6Al4V structures : Driving cellular response by modulating physical and chemical properties. Mater. Sci. Eng. C. 2019;98:705-16. doi:10.1016/j.msec.2019.01.016.

[45] Bobbio LD, Otis RA, Paul J, Dillon RP, Shapiro AA, Liu Z, Beese AM. Acta Materialia Additive manufacturing of a functionally graded material from Ti-6Al-4V to Invar : Experimental characterization and thermodynamic calculations. Acta Mater 2017;127:133-42. doi:10.1016/j.actamat.2016.12.070.

[46] Li W, Karnati S, Kriewall C, Liou F, Newkirk J, Brown KM, Seufzer WJ. Fabrication and characterization of a functionally graded material from Ti6Al-4V to SS316 by laser metal deposition. Addit. Manuf. 2017;14:95-104. doi:10.1016/j.addma.2016.12.006.

[47] Onuike B, Bandyopadhyay A. Additive manufacturing of Inconel 718 - Ti6Al4V bimetallic structures. Addit. Manuf. 2018;22:844-51. doi:10.1016/j.addma.2018.06.025.

[48] Wang X, Xu S, Zhou S, Xu W, Leary M, Choong P, Qian M, Brandt M, Xie YM. Topological design and additive manufacturing of porous metals for bone scaffolds and orthopaedic implants: A review. Biomaterials 2016;83:127-41. doi:10.1016/j.biomaterials.2016.01.012.

[49] Bartolomeu F, Dourado N, Pereira F, Alves N, Miranda G, Silva FS. Additive manufactured porous biomaterials targeting orthopedic implants: A suitable combination of mechanical, physical and topological properties. Mater. Sci. Eng. C. 2020;107 110342. doi:10.1016/j.msec.2019.110342.

[50] Taheri M, Saedi S, Sadi A, Karamooz MR. Mechanical and shape memory properties of porous Ni50.1Ti49.9 alloys manufactured by selective laser melting, J. Mech. Behav. Biomed. Mater. 2017;68:224-31. doi:10.1016/j.jmbbm.2017.01.047.

[51] Ataee A, Li Y, Brandt M, Wen C. Ultrahigh-strength titanium gyroid scaffolds manufactured by selective laser melting (SLM) for bone implant applications. Acta Mater 2018;158:354-68. doi:10.1016/j.actamat.2018.08.005

[52] Weißmann V, Wieding J, Hansmann H, Laufer N, Wolf A, Bader R. Specific Yielding of Selective Laser-Melted Ti6Al4V Open-Porous Scaffolds as a Function of Unit Cell Design and Dimensions. Metals (Basel) 2016;6:166. doi:10.3390/met6070166.

[53] Arabnejad S, Johnston RB, Ann J, Singh B, Tanzer M, Pasini D. High-strength porous biomaterials for bone replacement : A strategy to assess the interplay between cell morphology, mechanical properties, bone ingrowth and manufacturing constraints. Acta Biomater 2016;30:345-56. doi:10.1016/j.actbio.2015.10.048.

[54] Wang X, Speirs M, Kustov S, Vrancken B, Li X, Kruth JP, Van Humbeeck J. Selective laser melting produced layer-structured NiTi shape memory alloys with high damping properties and Elinvar effect. Scr. Mater. 2018;146:246-50. doi:10.1016/j.scriptamat.2017.11.047.

[55] Saedi S, Shayesteh Moghaddam N, Amerinatanzi A, Elahinia M, Karaca HE. On the effects of selective laser melting process parameters on microstructure and thermomechanical response of Ni-rich NiTi. Acta Mater 2018;144:552-60. doi:10.1016/j.actamat.2017.10.072.

[56] Van Bael S, Chai YC, Truscello S, Moesen M, Kerckhofs G, Van Oosterwyck H. Acta Biomaterialia The effect of pore geometry on the in vitro biological behavior of human periosteum-derived cells seeded on selective laser-melted Ti6Al4V bone scaffolds. Acta Biomater 2012;8:2824-34. doi:10.1016/j.actbio.2012.04.001

[57] Ryan G, Pandit A, Apatsidis DP. Fabrication methods of porous metals for use in orthopaedic applications. Biomaterials 2006;27:2651-70. doi:10.1016/j.biomaterials.2005.12.002. 
[58] B. Thavornyutikarn, N. Chantarapanich, Q. Chen, Bone tissue engineering scaffolding : computer-aided scaffolding techniques, 2014. doi:10.1007/s40204-014-00267.

[59] Johnson Matthey Medical Components, Nitinol Properties, (2017). http://jmmedical.com/resources/221/Nitinol-Technical-Properties.html.

[60] Frost HM. A 2003 update of bone physiology and Wolff s law for clinicians. Angle Orthod 2004;74:3-15

[61] Piccinini M, Cugnoni J, Botsis J, Ammann P, Wiskott A. Numerical prediction of peri-implant bone adaptation: Comparison of mechanical stimuli and sensitivity to modeling parameters. Med. Eng. Phys. 2016;38:1348-59. doi:10.1016/j.medengphy.2016.08.008.

[62] Madeira S, Pinto AMP, Rodrigues LC, Carvalho O, Miranda G, Reis RL, Caramês J, Silva FS. Effect of sintering pressure on microstructure and mechanical properties of hot-pressed Ti6Al4V-ZrO 2 materials. Mater. Des. 2017;120:394-403. doi:10.1016/j.matdes.2017.02.038.

[63] Chen CL, Richter A, Thomson RC. Investigation of mechanical properties of intermetallic phases in multi-component $\mathrm{Al}-\mathrm{Si}$ alloys using hot-stage nanoindentation. Intermetallics 2010;18:499-508. doi:10.1016/j.intermet.2009.09.013.

[64] Chen LY, Huang JC, Lin CH, Pan CT, Chen SY, Yang TL, Lin DY, Lin HK, Jang JSC. Anisotropic response of Ti-6Al-4V alloy fabricated by 3D printing selective laser melting. Mater. Sci. Eng. A. 2017;682:389-95. doi:10.1016/j.msea.2016.11.061.

[65] Kao WH, Su YL, Horng JH, Chang CY. Tribological, electrochemical and biocompatibility properties of Ti6Al4V alloy produced by selective laser melting method and then processed using gas nitriding, $\mathrm{CN}$ or Ti-C:H coating treatments. Surf. Coatings Technol 2018;350:172-87. doi:10.1016/j.surfcoat.2018.07.011.

[66] Wang R, Gu D, Xi L, Lin K, Guo M, Zhang H. Selective laser melted TiB2/Ti6Al4V graded materials and first-principle calculations. Mater. Lett. 2019;254:33-6. doi:10.1016/j.matlet.2019.07.015.

[67] Xue W, Wang C, Chen R, Deng Z. Structure and properties characterization of ceramic coatings produced on Ti-6Al-4V alloy by microarc oxidation in aluminate solution. Mater. Lett. 2002;52:435-41. doi:10.1016/S0167-577X(01)00440-2.

[68] Kao WH, Su YL, Horng JH, Chang CY. Surface \& Coatings Technology Tribological, electrochemical and biocompatibility properties of Ti6Al4V alloy produced by selective laser melting method and then processed using gas nitriding. $\mathrm{CN}$ or Ti-C : $\mathrm{H}$ coating treatments 2018;350:172-87. doi:10.1016/j.surfcoat.2018.07.011.
[69] Marattukalam JJ, Singh AK, Datta S, Das M, Balla VK, Bontha S, Kalpathy SK. Microstructure and corrosion behavior of laser processed NiTi alloy. Mater. Sci. Eng. C. 2015;57:309-13. doi:10.1016/j.msec.2015.07.067.

[70] Kumar S S, Marandi L, Balla VK, Bysakh S, Piorunek D, Eggeler G, Das M, Sen I. Microstructure - Property correlations for additively manufactured NiTi based shape memory alloys. Materialia 2019;8 100456. doi:10.1016/j.mtla.2019.100456.

[71] Saedi S, Turabi AS, Andani MT, Haberland C, Karaca H, Elahinia M. The influence of heat treatment on the thermomechanical response of Ni-rich NiTi alloys manufactured by selective laser melting, J. Alloys Compd 2016;677:204-10. doi:10.1016/j.jallcom.2016.03.161.

[72] American Society for Testing and Materials (ASTM), F136-12a Standard Specification for Wrought Titanium-6Aluminum-4Vanadium ELI (Extra Low Interstitial) Alloy for Surgical Implant Applications (UNS R56401), (2013) 6-10. doi:10.1520/F013612A.2.

[73] Z. Li, C. Liu, B. Wang, C. Wang, Z. Wang, F. Yang, C. Gao, H. Liu, Y. Qin, J. Wang, RSC Advances properties, roughness and bone ingrowth capacity, (2018) 12471-12483. doi:10.1039/c7ra13313h

[74] Galarraga H, Warren RJ, Lados DA, Dehoff RR, Kirka MM. Fatigue crack growth mechanisms at the microstructure scale in as-fabricated and heat treated Ti6Al-4V ELI manufactured by electron beam melting (EBM). Eng. Fract. Mech. 2017;176:263-80. doi:10.1016/j.engfracmech.2017.03.024.

[75] Yin S, Yan X, Chen C, Jenkins R, Liu M, Lupoi R. Hybrid additive manufacturing of Al-Ti6Al4V functionally graded materials with selective laser melting and cold spraying. J. Mater. Process. Technol. 2018;255:650-5. doi:10.1016/j.jmatprotec.2018.01.015.

[76] Bayraktar HH, Morgan EF, Niebur GL, Morris GE, Wong EK, Keaveny TM. Comparison of the elastic and yield properties of human femoral trabecular and cortical bone tissue, J. Biomech 2004;37:27-35. doi:10.1016/S0021-9290(03)00257-4. 